current between the equator and the doldrums is always from some point near east." I

Here, then, was another actual confirmation of Siemens's theory. Two facts-the diffusion of the Krakatão dust, and Abercromby's observations--supported Siemens's theory of air circulation, yet doubts were not quite removed. Voices were loud against the Krakatão hypothesis and against Abercromby's observations, which allowed another explanation to appear possible. Meteorologists delayed mostly to accept Siemens's theory, because a theoretical, mathematical establishment of it was still lacking. But this was given, as before observed, by Oberbeck, a year or so ago. He arrived at formulæ by which Siemens's theory could be reproduced.

Now, in fact, nothing more was wanting. Siemens's system was confirmed on all sides, by facts and by mathematical treatment. The chief merit for this is certainly due to Oberbeck. Before I bring to your notice the system of the general circulation of the atmosphere, such as it is given by the present state of research, I must allude to one other point in Siemens's expositionnamely, the influence which the general circulation of the atmosphere should have on the origin of cyclones and anticyclones in our latitudes.

The origin of the maxima ought to be due to the fact that the air flowing from lower to higher latitudes is checked in consequence of the convergence of meridians, and so produces an increase of pressure. Thus we get the maxima, or anticyclones. If, then, in consequence of this increase of pressure below, air flows out laterally, and, in consequence of the interference, the confined current turns more to the eastward, it must carry the lower strata with it, and give rise to a rarefaction, causing a minimum or cyclone. But this is carried away as a whole by the general current, and thus the progression of cyclones is also explained.

Siemens holds very strongly to this explanation, principally because it contains a force which explains the energy which is accumulated in anticyclones and cyclones, and which refers finally to the heat of the sun, that maintains the general circulation. But I fear he has overshot the mark here. The meridians converge in the southern hemisphere the same as in the northern. Why, then, do almost constant west winds prevail there below, without interference of currents, while with us an almost uninterrupted system of driving cyclones and anticyclones exists? Does not this prove that in the formation of cyclones. and anticyclones another factor is at work, and might not this perhaps depend on the peculiar distribution of land and water in the northern hemisphere? Upon this point Siemens will have to modify his views.

From my analysis we can easily sketch the outline of the general circulation of the atmosphere which corresponds to the present state of the science.

In consequence of the unequal heating of the sun and of the rotation of the earth, air currents occur at all parts of the globe. These currents are easterly between $35^{\circ} \mathrm{N}$. and $35^{\circ} \mathrm{S}$. latitude, and westerly outside this zone.

In the former zone the easterly currents on the earth's surface (in the northern hemisphere) are more north-easterly and northerly the nearer we approach latitude $35^{\circ}$, while in the higher strata they constantly become more southerly as we approach latitude $35^{\circ}$. This explains the circulation between the equator and latitude $35^{\circ}$. An upper south-west trade-wind entirely fails in this region. ${ }^{2}$ At or near the equator a calm zone must be formed at the earth's surface, where the meridional components of the north-east and south-east trades ascend, but the height of the calm-zone cannot be considerable. Exactly over the calm-zone a pure east wind and the strongest of the whole zone will blow, and the higher the strata under consideration the stronger it will be.

In latitude $35^{\circ} \mathrm{N}$. and S., calms exist at the earth's surface. The air, which has an ascending motion in the equatorial calm, has here a descending movement. But above, the current directed polewards continues to exist. Outside this great region, to the north and south, west winds will prevail ; while above, the south-west (or the north-west) trade-wind blows, which in higher latitudes will become more and more westerly. At the earth's surface, air in south-westerly or north-westerly

I Mr. Abercromby afterwards modified this opinion (NATURE, vol. xxxix p. 437). - Translator.

2 This statement as to the failure of the upper south-west trade-wind between the equator and lat. $35^{\circ}$ was afterwards modified (see Das Wetter, 189o, p. 158).-Translator.

NO. I I 73, VOL. 45$]$ motion flows from the zone of high pressure at latitude $35^{\circ}$, which becomes more westerly with increasing latitude. At a mean altitude, however, air flows again from the poles towards latitude $35^{\circ}$ as a north. west wind.

This is the picture of the general circulation of the atmosphere according to the latest researches. There is undoubtedly much to be completed, and it presents many dark points which remain to be cleared up, but on the whole it possesses every guarantee of truth and reality, and will doubtless soon be generally accepted. The question of the effect upon cyclones and anticyclones of this general circulation of the atmosphere will certainly come to the front, but we shall have to wait for a considerable time for a satisfactory solution of the problem.

\section{RELATION OF VOLTAIC ELECTROMOTIVE FORCE TO MOLECULAR VELOCITY.}

I $\mathrm{N}$ a recent research published in vol. viii., p. 63, of the Proceedings of the Birmingham Philosophical Society, 1892, it is shown, by means of an extensive series of sixty-four tables of measurements of mean volta electromotive force, that the dilution of the liquid of a voltaic cell by means of water or alcohol, the liquefaction of either the positive or negative metal of the cell by means of mercury, the dilution of either of these amalgams by means of mercury, or the dilution of one solid metal by means of another in an alloy, is universally attended by an increase of mean electromotive force of the diluted and diluting substances, and consequently also of the actual electromotive force of the diluted one, provided that in all cases no chemical union or other chemical change occurs in the mixture. The manifest explanation of this extensive general result is that, by the act of solution or dilution, the molecules of the active substance are separated farther apart, and consequently acquire increased velocity of motion. In proportion, however, as chemical union occurs, the gain of electromotive force diminishes and is converted into a loss, and the loss is larger in proportion as the chemical union is stronger. The method enables chemical compounds in alloys, amalgams, and electrolytes to be distinguished from mere mechanical mixtures.

G. GORE.

\section{SCIENTIFIC SERIAISS.}

IN the Botanical Gazette for February and March, Miss Alice Carter has an interesting paper on evolution in methods of pollination. She points out that the larger proportion of Monocotyledons are either anemophilous or hydrophilous, and this is undoubtedly an earlier method of pollination than the entomophilous. Of the twenty-three natural orders which comprise more than 1000 species, only five are characterized by inconspicuous flowers. Of these, four, viz. the Cyperaceæ, Gramineæ, Urticaceæ, and Piperaceæ, are probably ancestral types, the fifth, Euphorbiaceæ, degenerate. It is probable that the period of the appearance of Dicotyledons was also that of the development of our great groups of insects. The first step towards the attraction of insects was probably the colouring of the stamens, as in Thalictrum and Plantago; then the development and colouring of the corolla, and the production of saccharine secretions. The most highly developed orders appear to be those in which the number of parts in a floral whorl is small, as the Violaceæ, Compositæ, Labiatæ, and Scrophulariaceæ.- $\mathrm{Mr}$. P. H. Rolfs has an article on the Seed-coats of Malvaceæ; and Mr. Chas. Robertson continues his researches on Flowers and insects.

In the Fournal of Botany for March and April, Mr. E. A. L. Batters describes and figures a new marine alga, Gonimophyllum Buffha mi, the type of a new genus. It belongs to the Delesseriacex, an order of Florideæ, and is epiphytic on Nitophyllum laceratum, being in fact nearly allied genetically to its host-plant. It was obtained from the coast near Deal.-Mr. R. J. Harvey Gibson describes the hitherto unknown antherids of Polysiphonia elongella, the mode of escape and conjugation of the zoogametes of Enteromorpha compressa, and the mode of development of the spores of British marine species of Chantransia.-Mr. E. G. Baker continues his Synopsis of the genera and species of Malveæ; and Mr. W. H. Clarke his First records of British 
flowering plants.-The other articles are of interest specially to British botanists.

THE American Meteorological fournal for February contains a carefully prepared summary of the proceedings of the International Meteorological Conference at Munich from August 26 to September 2, I891, by A. L. Rotch. As we have already given a brief account of the Conference, and the report will shortly be published, we need not further refer to Mr. Rotch's article.-The Meteorological station of Naha, Liukiu Islands, Japan, by Y. Wada, of the Tokio Observatory. The station was established in July 1890 , and is very favourably situated for the study of the typhoons of the China and Japan seas, as a great many pass near the station. As soon as the island is connected by telegraph with Kiushu it will be the most important of all the Japanese stations for storm-warnings on the coasts of China, Corea, and Siberia. - The wind-rush at Washington, D.C., on November 23, 189r, by Prof. H. A. Hazen. This violent'gale was probably the most destructive that has ever been noted at that place. It passed across the city from a south or south-west direction; the wind at the Weather Bureau reached 60 miles per hour [8o miles and upwards have been recorded in this country], but the effects show that during the gusts it must have been very much greater. A cloud-burst occurred during the gale, and the water in a canal which is 25 feet wide rose about 8 feet in a few minutes. The curve showing the barometric oscillation will be found in the Monthly Weather Review for that month.

Bulletin of the New York Mathematical Society, vol. i. No. 5 (New York, February).-This number opens with a carefully drawn up account of Klein's modular functions, by F. N. Cole; the occasion being an able presentation of the theory in the work "Felix Klein: Vorlesungen tiber die Theorie der elliptischen Modulfunctionen, ausgearbeitet und vervollständigt von Dr. R. Fricke." Of this Mr. Cole remarks : "The clearness of treatment and skilful grouping of the many intricate features of the subject have rendered this theory now thoroughly accessible. Dr. Fricke has contributed many of the intermediate steps necessary to the symmetry and completeness of the subject." The reviewer, also a pupil of Klein, supplies many little bits of personal narrative. - The next article is an abstract by " $\mathrm{S}$. N." of the periodic perturbations of the longitudes and radii vectores of the four inner planets of the first order as to the masses, computed under the direction of Simon Newcomb. Then follows a brief sketch of solution of questions in the theory of probability and averages, by G. B. Zerr. This pamphlet forms Appendix ii. to the "Mathematical Questions .. from the Educational Times."-The notes give a brief account of the Proceedings of the Society, and also contain an addendum to Prof. Hathaway's article (in No 3), "Early History of the Potential."

Bulletin de l'Académie des Sciences de St. Pétersbourg, nou' velle série, t. ii., No. 2.-A preliminary communication (in German) upon the rocks collected by M. Lopatin on the Podkamennaya Tunguska. The series of Archaic rocks of Siberia, which formerly were described as dolerites, and which so constantly occur in Siberia, offer great difficulties as to their petrographical determination, well known to all geologists. The author now begins the publication of a most welcome monograph on these rocks, based upon no less than 450 samples analyzed under the microscope. The extension of these rocks is immense, as they seem to spread, with small interruptions, in the shape of an immense zone covering the space between $50^{\circ}$ and $70^{\circ} \mathrm{N}$. lat., over Siberia, North America, South Greenland, Ireland, Scotland, Norway, Sweden, and North Russia. The author describes them as "Palæozoic traps," or typical "plagioclase-pyroxene-olivine rocks," which offer all possible gradations in their evolution. The communication being but a preliminary one, nine different "types" are described and illustrated.-On a new leucite rock from the same locality, by the same author, also illustrated by a plate.-On the Perseids observed in Russia in I890, by Th. Bredichin (in French). The observations were made by several astronomers at Pulkova, Ostrogojsk, Kineshma, Moscow, and Libau. The weather was not favourable from August $\mathbf{I}$ to 9, and quite unfavourable on the I 2 th and 1 3 th. Nevertheless, the author arrives at in. teresting results in comparing the centres of radiation of the meteors in 1890 with the orbit of the comet 1862 III. The centres of radiation are given on a separate plate-Combina- tion of the aldehydes with azoic compounds, by J. Bardilowsky (French), being an inquiry into the mechanism of the reaction between the aldehydes and the salts of aromatic amines. - Note on the heat of combination of bromine and iodine with magnesium, by N. Beketoff (French). - On Seldjuk verses, by C. Saleman (in German).-Astronomical determinations in North Russia, by O. Backlund (in German).-Remarks upon the Upper Silurian deposits of the Baltic provinces, in connection with the work of Prof. W. Dames (with a map), by Prof. Fr. Schmidt.

Memoirs of the Kazan Society of Naturalists, vol, xxiii., I to 5, and Proceedings. - On the tundra of the Kanin peninsula, by A. I. Jacoby, with a map. The author explored the western coast, and gives many interesting facts as to the flora of the tundra and its inhabitants. - On the biology of the Helianthus annuus, by A. Gordyaghin. Having discovered that the leaves of the sunflower are visited by nearly twenty different species of insects, and that some of them, especially the ants (Myrmica lavinodis and Lasius niger), suck the leaves, the author suspected the existence of "extra-nuptial " nectariæ-the supposition being confirmed by a similar observation previously made by Delpino; and he made experiments to ascertain whether drops of nectar do appear on the leaves. The observations have confirmed the supposition; they are being continued.-On the noxious insects of the model farm of the Kazan School, by A. Smirensky.-On the means of measuring the absorbing power of the soil, by B. Sorokin. The Proceedings contain : a list of 300 birds of the province of Astrachan, by W. Kleb. nikoff : the report of a Committee nominated for the exploration of the soil in the province of Kazan; a note on the produce of a dry distillation of birch bark; and a report upon ornithological researches in the province of Kazan, with a list of all noticed birds.

\section{SOCIETIES AND ACADEMIES. LONDON.}

Zoological Society, April 5.-W. T. Blanford, F.R.S., in the chair. - The Secretary read a report on the additions that had been made to the Society's Menagerie during the month of March I892,-Mr. Sclater exhibited and made remarks on the heads of a pair of Swayne's Antelopes (Bubalis swaynei) obtained by Mr. J. W. K. Clarke and his party in Somali-land, and sent for exhibition by Messrs. Rowland Ward and Co.-Prof. F. Jeffrey Bell read a note regarding the real habitat of the Land Planarian Bipalium kewense, which, as it appeared, was indigenous to one of the South Pacific islands. - A communication was read from Mr. Edgar A. Smith, on the Land Shells of St. Helena, based on a large and complete collection of the terrestrial Mollusks of that island made by Captain W. $\mathrm{H}$. Turton, R.E., and deposited in the British Museum. Mr. Smith estimated the total number of truly indigenous species of this group in St. Helena to be 27 , of which 7 only are now living on the island - the remainder having been exterminated by the destruction of the primæval forests. - Mr. F. E. Beddard read some notes on the anatomy of the Indian Darter (Plotus melanogaster), as observed in a specimen of this species recently living in the Society's Gardens.-Mr. Seebohm exhibited a specimen of a Pheasant from the valley of Zarafshan in Central Asia, which he referred to a new species, distinguishable from $P h$. principalis by its white collar, and proposed to call it $P h$. tarnorskii.--Mr. R. J. L. Guppy exhibited specimens of the animal, the teeth and jaws, and the shell and egg of Bulimus oblongus, and remarked briefly thereon.-Mr. G. B. Sowerby read descriptions of seven new species of Land-Shells from the United States of Colombia.-A communication was read from $\mathrm{Mr}$. W. Schaus, containing descriptions of some new species of Lepidoptera Heterocera from Brazil, Mexico, and Peru.

Geological Society, March 23.-W. H. Hudleston, F.R.S., President, in the chair.-The following communications were read:-On the occurrence of the so-called Viverra Hastingsice of Hordwell in the French phosphorites, by $R$. Lydekker.- Note on two Dinosaurian foot-bones from the Wealden, by R. Lydekker. - On the microscopic structure, and residues insoluble in hydrochloric acid, in the Devonian Limestone of South Devon, by Edw. Wethered. Microscopic examination of the Devonian Limestones of South Devon shows that they have been built up by calcareous organisms, but that

No. 1173 , VOL. 45] 